HARRAN ÜNIVERSITESI MÜHENDISLIK DERGisi

HARRAN UNIVERSITY JOURNAL OF ENGINEERING

e-ISSN: 2528-8733

\section{HARRAN ÜNIVERSITTESI MÜHENDİSLİK DERGISİ}

HARRAN UNIVERSITY JOURNAL of ENGINEERING

e-ISSN: 2528-8733 (ONLINE)

URL: http://dergipark.gov.tr/humder

Gıda Analizlerinde Hasarsız Akustik Yöntemlerin Kullanımı

Using of Non-destructive Acoustic Methods in Food Analyses

Yazar(lar) (Author(s)): Eylem ODABAŞ ${ }^{1}$, Hülya ÇAKMAK ${ }^{2}$

${ }^{1}$ ORCID ID: 0000-0001-5034-1370

${ }^{2}$ ORCID ID: 0000-0002-4936-939X

Bu makaleye şu şekilde atfta bulunabilirsiniz (To cite to this article): Odabaş, E., Çakmak, H., "Gıda Analizlerinde Hasarsız Akustik Yöntemlerin Kullanımı”, Harran Üniversitesi Mühendislik Dergisi, 6(1): 64-79, (2021).

Erişim linki (To link to this article): http://dergipark.gov.tr/humder/archive 


Mühendislik Dergisi

\title{
Gıda Analizlerinde Hasarsız Akustik Yöntemlerin Kullanımı
}

\author{
Eylem ODABAŞ ${ }^{1}$, Hülya ÇAKMAK ${ }^{2}, *$ \\ ${ }^{1}$ Hitit Üniversitesi, Fen Bilimleri Enstitüsü, Gıda Mühendisliği ABD, Merkez/ Çorum \\ ${ }^{2}$ Hitit Üniversitesi, Mühendislik Fakültesi, Gıda Mühendisliği Bölümü, Merkez/Çorum
}

\begin{abstract}
$\underline{0 ̈ z}$
Makale Bilgisi

Başvuru: 19/10/2020

Kabul: $30 / 04 / 2021$

\section{Anahtar Kelimeler}

Hasarsız yöntem,

Gıda ürünlerin kalitesinin değerlendirilmesinde hasar veren gıda analiz yöntemlerine alternatif olarak geliş̧irilen ve hasar vermeyen spektroskopik ve kromatografik tekniklerin yanı sıra, mekanik yöntemlerin kullanımının son yıllarda arttı̆̆ 1 görülmektedir. Bu teknikler arasında yer alan akustik ve ultrasonik tekniklerin özellikle büyük hacimli gıdaların kalitesinin değerlendirilmesinde kullanımı ile analiz sırasında örneklerin kaybının engellenebileceği ve bu şekilde ekonomik bir kazanç sağlanacağı öngörülmektedir. Akustik teknikler, büyüklük, hacim, şekil ve doku fark etmeksizin birçok gıdanın sertlik, iç kusur, olgunluğunun belirlenmesinde ve gıdaların seçilen kalite özelliklerine göre sınıflandırılmasında başarıyla kullanılabilmektedir. Bu derleme çalışmasında ağılıklı olarak meyve ve sebzelerin kalitesinin incelenmesinde kullanılan akustik teknikler, lazer Doppler titreşim ve ultrasonik yöntemler incelenmiş olup, farklı gida gruplarında bu tekniklerin kullanımıyla elde edilen sonuçlar detaylı olarak kıyaslanmıştır.
\end{abstract}

Akustik,

Lazer Doppler,

Ultrason

\section{Keywords}

Non-destructive method,

Acoustic vibration,

Laser Doppler,

Ultrasound

\section{Using of Non-destructive Acoustic Methods in Food Analyses}

\begin{abstract}
In recent years, the use of non-destructive food analysis methods such as; spectroscopic, chromatographic techniques and mechanical methods which are developed as an alternative to the classical destructive analysis techniques for evaluation of the quality of food products is increased. By employing acoustic and ultrasonic techniques, the loss of food samples during application of the analysis can be prevented, especially the quality determination of large-volume foods, and thus possible economic gain will be achieved due to the food loss. Acoustic techniques, regardless of the size, volume, shape and texture of food can be successfully used in determining the firmness, internal defects and maturity of many foods and for classification of these foods according to the selected quality parameters. In this review, the acoustic techniques, laser Doppler vibrometry and ultrasonic methods, which are used to evaluate mostly the quality of fruits and vegetables are discussed, and the results of different food groups obtained from these techniques are compared in detail.
\end{abstract}

\section{GİRIŞ (INTRODUCTION)}

Gıdaların dış görünüşü ve rengi gıda ürününü satın alınırken tüketicinin dikkatini çeken ilk kalite özelliklerindendir. Olgunlaşmamış ya da aşırı olgunlaşmış meyve ve sebzeler mekanik hasar, yumuşama, fizyolojik ve mikrobiyolojik bozulmalara karşı duyarlı olduğu için raf ömürleri sinırlıdır [1]. Dolayısıyla bu ürünlerin kalite özelliklerinin dikkatle değerlendirilmesi raf ömrünü uzatma ve ekonomik değerinin arttırılmasına yardımcı olacaktır.

Gıdaların kalite özellikleri iç ve dış kalite özellikleri olarak iki ana kategoriye ayrılmaktadır. İç kalite özellikleri; besin bileşimi, olgunluk, doku, iç kusurlar veya hastalıklar, (çekirdek ve iç kısmının boş, çukur veya çürük olması, mikrobiyal bozulma vb.), kimyasal bulaşanlar ile tat ve aromayı içermektedir. Diş kalite özellikleri ise; boyut, şekil, renk, çürükler (delinme, yanık, çatlaklar, yarıklar, filizler vb.) ve yabancı maddeleri içermektedir [2-8]. İç ve diş kalite özellikleri genellikle duyusal testler gibi görsel incelemeyle ya da gidaya hasar veren enstrümantal yöntemlerle analiz edilmektedir [4,9]. Meyve ve sebzelerin 
sertliğinin değerlendirildiği birçok çalışmada, tüm örnek yığınını temsil eden bir örnek seçilerek analizler gerçekleştirilmekte, analiz sonrasında ise örnek hasar gördüğ̈ için tekrar kullanılamamaktadır. Sertliğin enstrümantal değerlendirilmesinde, bir probun meyve veya sebze yüzeyi üzerine uyguladığı kuvvet ve örneğin proba verdiği tepki değerlendirilerek karmaşık tekstürel özellikleri tanımlamak için kullanılmaktadır. Yaygın olarak meyve olgunluğunu belirlemek için geliştirilen Magness- Taylor yöntemi (MT) [10], sünme [11] ve gerilim ölçüm yöntemleri [12] gıdaların tekstürel özelliklerinin incelenmesinde yararlanılan en temel yöntemlerdir. Ancak özellikle meyve ve sebzelerin hasar veren analizlerle ölçümlerinde sınırlı sayıda örnek kullanımı, hasat olgunluğunun toplam dağılımını etkili bir şekilde açıklayamamakta ve depolama sırasında aynı örnekte oluşabilecek değişikliklerin takibini zorlaştırmaktadır. Bu nedenle, bu gibi ürünlerin değerlendirmesi için hasarsız yöntemlerin kullanımının kalite kontrolü için belirgin avantajları olacağı düşünülmektedir.

Hasarsız yöntemler, analiz süresinin ve maliyetin azaltılmasıyla birlikte analizin doğruluğunu ve tekrarlanabilirliğini arttırdığı için bu yöntemlerin kullanımı bir gereklilik haline gelmiştir [13]. Hasarsız yöntemler, gerçek zamanlı ve çevrimiçi uygulamalara izin vermektedir. Ayrıca gıda kalitesinin otomatik olarak izlenmesini sağlayarak, analizler öncesi numune hazırlığı gerektirmemektedir. Meyve ve sebzeler, tür, büyüklük, şekil, renk, olgunluk, iç ve dış kusurlar, hastalıklar veya mikrobiyal bulaşma varlığına göre hasarsız yöntemlerle sınıflandırılıp değerlendirilebilmektedir. Hasarsız analiz yöntemleri genel olarak spektroskopik yöntemler, X-1şını bilgisayarlı tomografi (CT) ve mekanik yöntemler olarak üç ana grupta incelenebilmektedir. Mekanik yöntemler ise elastik deformasyon ölçümü, örnekte ses iletim hızının belirlenmesi ve akustik rezonans ölçümü tekniklerini içermektedir. Akustik analiz, gıdalarda ses dalgalarının yayılmasını ve yansımasının incelendiği bir yöntem olup 1970'li yılların sonundan itibaren gevreklik ve çıtırlık gibi tekstürel özelliklerin incelenmesinde kullanılmaya başlanmıştır [14]. Şekil 1'de görüldügü gibi mekanik yöntemler dört ana gruba ayrılmaktadır. Bu yöntemler gıdaların hasarsız sertlik belirlemesinde yaygın olarak kullanılmaktadır $[3,14]$. Bu derlemede gıdaların hasarsız ölçümleri için uygulanan mekanik yöntemlerin farklı gıdalarda kullanımı detaylı olarak incelenmiştir.

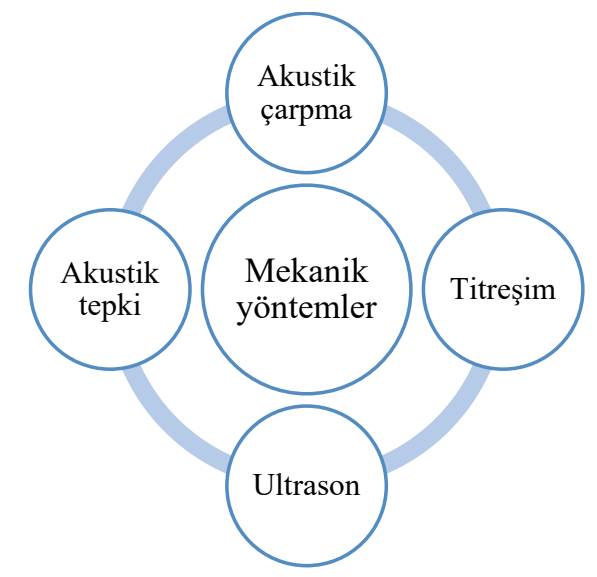

Şekil 1. Hasarsız mekanik analiz yöntemleri

\section{AKUSTIK YÖNTEMLER (ACOUSTIC METHODS)}

\subsection{Akustik Çarpma Yöntemi (Acoustic Impact Method)}

Akustik çarpma yönteminde meyve veya sebzeler belirli bir yüksekten paslanmaz çelik plaka şeklinde bir yük hücresi üzerine bırakılmakta ve çarpma anında oluşan ses sinyalleri bir mikrofon yardımıyla dijital sinyal işlemcisine (DSP) aktarılmaktadır [15-18]. Alınan bu sinyallerin süresi, frekansı ve hızlı Fourier dönüşümü (FFT) alanı sinyal analizöründe görüntülenip kaydedilmektedir $[15,16,17]$. Ölçüm yapılacak gıda örneği konveyör bant üzerinde taşınabilmekte veya vakum etkisiyle tutunduğu kısımdan yük hücresine bırakılabilmektedir [15-18]. Örneğin analiz sırasında hasar görmesini engellemek için yük hücresi ince bir sünger ile kaplanabilmekte ve örneğin düştükten sonra elastik olmayan deformasyonunu engellemek amacıyla uygun bırakma yüksekliği seçilmektedir $[15,16]$. Akustik çarpma yöntemiyle yapılan çalışmalar incelendiğinde, çarpma sonrası veri kayıt süresi patates için 2 milisaniye iken [15], Antep fistığında 2 
milisaniye [18] olarak verilmiştir. Domatesin olgunluğunun incelendiği çalışmada ise olgunluğa bağlı olarak 1.6-2.2 milisaniye arasında veri alındığı görülmektedir [16]. Hurma olgunluğunun incelendiği çalışmada ise, verilen literatürden farklı olarak sinyal kayıt süresinin 500 milisaniyeye çıktığı görülmektedir [17]. Ayrıca çarpma sonrası kaydedilen veri noktası sayısının 150-1024 arasında değiştiği görülmektedir $[15,18,19]$.

Akustik çarpma yöntemi yapılan bir çalışmada patatesin iç kısımlarındaki boşlukları tespit etmek için kullanılmıştır [15]. Patateslerden, iç kısmı boş olan ve olmayan (sağlıklı) yumrular arasında ayrım yapmak için yaklaşık 0-201 Hz frekans aralığı belirlenmiş olup içi boş yumrularının tepe frekansının sağlıklı olanlardan daha düşük olduğu ve bu yöntemle \%98 üzerinde doğru sınıflandırma yapıldığı görülmüştür. Domateslerin olgunluğunun belirlenmesi için yapılan bir çalışmada, akustik çarpma yönteminden elde edilen sonuçların istatistiksel değerlendirmesi ve örneklerin gruplanması kümeleme analizi ve doğrusal diskriminant analiz ile gerçekleştirilmiştir [16]. Yapılan analizler sonucu akustik çarpma yönteminin domateslerin yarı olgun ve olgun olarak sinıflandırılmasında kullanılabileceği belirlenirken, kullanılan istatistiksel yöntemlerinin sınıflandırmadaki doğruluğu arttırdığı belirlenmiştir.

Mireei vd. [17] tarafından yapılan bir çalışmada, akustik çarpma yöntemi konveyör kullanılarak sürekli sistem haline getirilmiş ve hurmaların sertliğini belirlemek amacıyla kullanılmıştır. Hurmaların olgunlukları farklı seviyelerde olup sirasiyla; Kimri, Khark, Rutab ve en olgun olan Tamr olarak gruplandırılmış ve konveyör hızının meyve sertliğini belirlemekte kullanılan modeller üzerine etkisi incelenmiştir. Kaydedilen çarpma sinyali yanıtları kısmi en küçük kareler regresyon yöntemiyle sertlik tahmininde kullanılmış, en iyi sonuçların $\left(\mathrm{R}^{2}=0.80\right) 1.5 \mathrm{~m} / \mathrm{s}$ konveyör hızında ve tüm çarpma geçmişini içeren sinyaller kullanıldığında elde edildiği görülmüştür.

Akustik çarpma yöntemi yapılan bir diğer çalışmada, Antep fıstıklarını kabuklarının kapalı ya da açık olma durumuna göre sınıflandırılmıştır [18]. Kabukları kapalı olan örneklerin ilk 0.33 ms'de kabukları açık olana göre daha yüksek sinyal büyüklüğünde ses yaydığı görülürken, bu sinyal aralığından sonra kapalı kabuğu olan Antep fistıklarının, açık kabuklu olanlardan daha düşük sinyal büyüklüğünde ses yaydığı tespit edilmiştir. Ayrıca akustik yöntemle kapalı kabuklu Antep fıstığının, açık kabuklu olanlardan yaklaşık \%97 doğrulukta ayırt edilebildiği belirlenmiş̧tir.

Kivi meyvesinin olgunluğunu belirlemek amacıyla akustik çarpma yönteminden yararlanılan bir çalışmada, farklı düşme yüksekliklerinden $(2,4$ ve $6 \mathrm{~cm})$ bırakılan örneklerin akustik çarpmaya verdiği yanıt değerlendirilmiştir [19]. Örneklerin akustik tepki yanıtları ile toplam suda çözünür kuru madde, titre edilebilir asitlik, enstrümantal sertlik ve duyusal analiz sonuçları kıyaslanmış olup, sonuçlar çoklu doğrusal regresyon, geri yayılım yapay sinir ağları ve temel bileşen analizi- geri yayılım yapay sinir ağları ile incelenmiştir. Kivi örneklerinin tepki ölçüm plakasına mesafesinin ve diskriminant analiz türünün kivi olgunluğunun belirlenmesi üzerinde etkili olduğu ve en doğru tahminin (\%94.2 kalibrasyon ve \%92.1 validasyon doğruluğu) $6 \mathrm{~cm}$ düşme yüksekliği ve temel bileşen analizi- geri yayılım yapay sinir ağları analizi ile elde edildiği bulunmuştur. Benzer şekilde Ragni vd. [20] kivi olgunluğunu belirlemek için farklı düşme yükseklikleri $(1,1.5$ ve $2 \mathrm{~cm})$ ve konveyör hızlarının $(0.7,1$ ve $1.3 \mathrm{~m} / \mathrm{s})$ etkisini incelemişlerdir. Magness-Taylor sertliği değerini tahmin etmekte kullanılan modellerde en etkili parametresinin tepkinin pik kuvveti olduğu ve en iyi tahminin $\left(\mathrm{R}^{2}=0.82\right) 1 \mathrm{~cm}$ düşme yüksekliği ve $1 \mathrm{~m} / \mathrm{s}$ konveyör hızında elde edildiği belirlenmiştir.

Literatüre göre akustik çarpma yöntemi meyve ve sebzelerin olgunluk, sertlik, iç kusurlar ve örneklerin sınıflandırılmasında başarıyla kullanıldığı görülmektedir. Ancak çalışmalardan elde edilen sonuçlara göre, örneklerin düşme yüksekliği, sabit veya hareketli (konveyörle) ölçüm uygulanması ve akustik tepki yanıtlarının değerlendirildiği istatistiksel analizlerin, oluşturulan modellerin tahminleme gücü üzerinde etkili olduğu bulunmuştur (Tablo 1). Ayrıca seçilen düşme yüksekliklerinin, depolamanın ileriki aşamalarında örneklerde görünür hasar bırakabileceği belirtilmiştir [20]. 
Tablo 1. Akustik çarpma yönteminde kullanılan örneklerin parametreleri

\begin{tabular}{|l|c|c|c|c|c|}
\hline \multicolumn{1}{|c|}{ Örnek } & $\begin{array}{c}\text { Düşme } \\
\text { yüksekliği }\end{array}$ & $\begin{array}{c}\text { Konveyör } \\
\text { bant hızı } \\
(\mathrm{m} / \mathrm{s})\end{array}$ & Sinıflandırma & İstatistiksel analiz* & Kaynak \\
\hline Antep fistı̆̆ 1 & $38.1 \mathrm{~mm}$ & - & Kabuk açılı̆̆ 1 & Diskriminant analizi & {$[18]$} \\
\hline Domates & $15 \mathrm{~mm}$ & - & Olgunluk & DDA ve Scheffé testi & {$[16]$} \\
\hline Hurma & $10 \mathrm{~mm}$ & $1-1.5-2$ & Meyve sertliği & KEKK & {$[17]$} \\
\hline Kivi & $20-40-60 \mathrm{~mm}$ & - & Olgunluk & $\begin{array}{c}\text { Çoklu doğrusal regresyon } \\
\text { yöntemi ve TBA }\end{array}$ & {$[19]$} \\
\hline Kivi & $10-15-20 \mathrm{~mm}$ & $0.7-1-1.3$ & Meyve sertliği & $\begin{array}{c}\text { YSA ve çoklu regresyon } \\
\text { modeli }\end{array}$ & {$[20]$} \\
\hline Patates & $30 \mathrm{~mm}$ & - & Oyuk hasarı & Diskriminant analizi & {$[15]$} \\
\hline
\end{tabular}

*YSA: yapay sinir ağı, KEKK: kısmi en küçük kareler regresyon, DDA: doğrusal diskriminant analizi, TBA: temel bileşen analizi.

\subsection{Akustik Tepki Yöntemi (Acoustic Impulse Method)}

Akustik tepki yöntemiyle, meyve ve sebzelerin sertliği ve olgunluğu, örneklerin frekansları arasındaki korelasyon kullanılarak belirlenebilmektedir [21]. Bu yöntemde ilk olarak meyve ve sebzelerin doğal frekansları bir çubuk yardımıyla uygulanan tepkiye yanıt olarak belirlenmekte ve daha sonra tepki yanıtına bağlı olarak örneğin titreşiminden rezonans frekansları (RF) elde edilmektedir [22-24]. Ölçüm yapılacak örneğin üzerine temas etmeyecek şekilde yerleştirilen mikrofon ile mikrofonun tam karşından örneğe hafifçe vurularak çıkan ses sinyalleri işlenmektedir [24]. Zaman-frekans analiziyle işlenen sinyal değerlerine göre en yüksek frekans, birinci rezonans frekansı (f) olarak adlandırılmaktadır [23]. Bir örneğin RF'si; örneğin boyutu, yoğunluğu ve Poisson oranı ile orantılıdır. Poisson oranı, malzemelerin deformasyonunu ölçmek için kullanılan temel parametrelerden biri olup, malzemenin yükleme yönüne dik yönde genişlemesini veya büzülmesini açıklamaktadır [25]. Bazı çalışmalarda, tepki yöntemiyle sertlik tahmininde, meyve ve sebzenin kütlesinin doğal frekanslar üzerinde bir etkisi olduğu düşünülerek Eşitlik 2.2.1'de belirtildiği gibi meyve veya sebzenin kütlesi hesaplamalarda kullanılmıştır.

$$
\mathrm{S}=\mathrm{f}^{2} \times \mathrm{m}
$$

burada $\mathrm{f}$ birinci rezonans frekansını $(\mathrm{Hz})$ ve m meyve kütlesini $(\mathrm{g})$ göstermektedir. $\mathrm{Bu}$ denklemde elde edilen sonuçlar sertlik katsayısı (S) olarak kabul edilmektedir [29, 30]. Bu yöntemle elde edilen sonuçlar ile Young modülü, Magness-Taylor kuvveti ve sünme kuvveti arasındaki benzerlik incelerek meyvenin olgunluk durumuna bağlı sertliğinin hasarsız bir şekilde tahmini mümkün olmaktadır [26]. Ayrıca rezonans ölçüm tekniğinin, elma, şeftali ve karpuz gibi (Tablo 2) küresele yakın olan meyvelerin sertliğinin hasarsız olarak belirlenmesine daha uygun olduğu belirtilmiştir [22-24; 26-28]. Ölçüm yapılan örneklerin şekline bağlı oluşacak hataları azaltmak için, ağırlıkları benzer örneklerin seçilmesi ve örneğin ekvator kısmına eşit aralıklarla yerleştirilmiş üç ölçümünün ortalamasının alınması önerilmektedir [24; 30].

Kivi meyvesinin tekstürel özelliklerini değerlendirmek amacıyla yapılan bir çalışmada, hasarsız akustik tepki yöntemi ile hasar veren enstrümantal sertlik ölçümü sonuçları kıyaslanmıştır [31]. Kivi meyvesi farklı derecelerde olgunlaşması için etilen ile muamele edilmiş ve meyve yüzeyine bağlanan hoparlörden yayılan $500,1000,1500$ ve $2000 \mathrm{~Hz}$ frekanslardaki titreşimlere oluşan tepki, yine meyve yüzeyine tutturulan mikrofon ile osiloskopa aktarılmışıı. Meyvenin beyaz iç kısmı ile yeşil perikarp kısmı titreşimlere farklı yanıtlar verse de, genel olarak olgunlaşmanın artmasıyla ses yayılımında geçen zamanın her iki tabakada da düştüğü saptanmıştır. Li vd. [32], Gold3 ve Hayward kivi çeşitlerinin sertliğini belirlemek amaciyla Kiwifirm (KF), AWETA ${ }^{\mathrm{TM}}$ akustik sertliği (AF), sıkıştırma kuvveti $(\mathrm{CP})$ ve AWETA ${ }^{\mathrm{TM}}$ çarpma sertliği (IF) olmak üzere dört farklı hasarsız ölçüm yöntemi kullanmışlardır. Yapılan çalışmada her iki kivi çeşidi için depolama sırasında standart penetrometre ile elde edilen sonuçlar ile hasarsız ölçüm yöntemleriyle elde edilen sonuçlar arasında doğrusal bir ilişki olduğu bulunmuştur (Gold3: $\mathrm{R}^{2}=0.913-0.974$, Hayward: $\mathrm{R}^{2}=0.946-0.971$ ). Ancak meyvenin dış perikarpındaki değişimleri dikkate alan penetrometre ölçümleri depolama sırasındaki yumuşamaya bağlı olarak hızla düşerken, hasarsız ölçümlerde depolama sırasında değişimin benzer düzeyde olmaması sebebiyle depolamanın ilerleyen aşamalarında bu yöntemler arasındaki ilişkinin zayıfladığı görülmektedir. 
Sugiyama vd. [33] tarafından yapılan çalışmada, kavunların sağlamlığını ölçmek için meyveye hafif bir etki sağlayabilecek bir pistondan oluşan portatif tabanca ve iki mikrofondan oluşan bir cihaz geliştirilmişlerdir. Meyve üzerinei etki bir darbe çubuğuyla oluşturulurken, çubuk tarafindan üretilen titreşim meyvenin yüzeyine dağılarak meyve içinde üretilen ses dalgasının iletilmesi sağlanmaktadır. Bu ses dalgasının hızı, iki mikrofonun pik tepkisinin zamanlamasından tahmin edilmiştir. İki akustik sinyalin çapraz korelasyonundan hesaplanan iletim hızı ile hasar veren enstrümantal testlerden elde edilen görünür elastikiyet arasında yüksek korelasyon olduğu belirlenmiştir $\left(\mathrm{R}^{2}=0.94\right)$. Sugiyama [34], aynı cihazı armut sertliğini ölçmek için kullanmış ve iki akustik sinyalin çapraz korelasyonundan iletim hızı hesaplayarak hasar veren analizden elde edilen görünür elastikiyet ile akustik yöntem arasında yüksek korelasyon olduğu belirlenmiştir $\left(\mathrm{R}^{2}=0.94\right)$. Ayrıca bu çalışmada akustik yöntemle elde edilen ses yayılım hızının armut çeşitlerine göre farklılık gösterdiği, küresele daha yakın olan armut çeşidinde korelasyonun daha yüksek olduğu görülmektedir. Subedi ve Walsh [35] tarafından yapılan çalışmada ise, şeftali, muz ve mango örneklerinin meyve sertliğini belirlemek için yakın kızılötesi spektroskopisi ve titreşim dalga hızı ölçüm tekniklerinin penetrometre sonuçlarıyla uyumu incelenmiştir. Titreşim hızını belirlemekte kullanılan tabanca meyve yüzeyine yavaşça dokunurken, meyve eti içerisindeki titreşim iki mikrofonla veri işleyicisine aktarılmıştır. Meyvelerin olgunlaşmasına bağlı olarak ses hızı; mangoda $84 \mathrm{~m} / \mathrm{s}$ 'den $39 \mathrm{~m} / \mathrm{s}$ 'ye, muzda $29 \mathrm{~m} / \mathrm{s}$ 'den $14 \mathrm{~m} / \mathrm{s}^{\prime}$ ye ve şeftalide $28 \mathrm{~m} / \mathrm{s}^{\prime}$ den $15 \mathrm{~m} / \mathrm{s}^{\prime}$ ye düşmüştür. Penetrometreden elde edilen sonuçlar ile spektroskopi sonuçları arasında çapraz doğrulama sonuçları muz, mango ve şeftali için sırasıyla $\mathrm{R}^{2}=0.92,0.86$ ve 0.79 iken, penetrometre ve ses hızı tekniği arasındaki değerler sırasıyla $\mathrm{R}^{2}=0.88,0.77$ ve 0.58 bulunmuştur. Ancak spektroskopik yöntemle yapılan ölçümlerin meyve eti yerine kabuğunun ölçümleriyle ilgilenmesi sebebiyle akustik yöntemin sertlik belirlemede daha uygun olduğu belirtilmiştir.

Schotte vd. [36], domatesin $2-20^{\circ} \mathrm{C}$ arasındaki sıcaklıklarda depolanması sırasında, sertlik faktörünün değişimini akustik tepki yöntemiyle incelemişler ve duyusal analiz yöntemleriyle akustik ölçüm yöntemi arasında logaritmik bir ilişki olduğunu belirlemişlerdir. Ayrıca sertlik faktörünün azalma modelinin farklı depolama sıcaklarında da geçerli olduğunu belirtmişlerdir. De Belie vd. [24] ise Cox's Orange Pippin, Elstar ve Jonagold çeşidi elmaların sertliğini penetrometre ve akustik tepki yöntemiyle elmanın kızarık ve kızarık olmayan taraflarında ölçmüşlerdir. Elmaların hasarlı ve hasarsız ölçüm sonuçları arasında yüksek korelasyon olduğu belirlenmiş olup, korelasyonun elmanın kızarık olan taraflarında daha yüksek olduğu bulunmuştur (Cox: $\mathrm{R}^{2}=0.98$, Elstar: $\mathrm{R}^{2}=0.93$ ve Jonagold: $\mathrm{R}^{2}=0.98$ ). Ayrica depolama sirasında elmada oluşan tekstür değişiminin akustik yöntemle daha hassas olarak tespit edilebildiği bulunmuştur. Elmalarla ilgili yapılan bir başka çalışmada, Pink Lady ve Pacific Rose elmalarının depolanması sırasında su kaybına bağlı mekanik özelliklerinde meydana gelen değişiklikler incelenmiştir [37]. Akustik sertlik ve elektrik tepkisini ölçmek için kullanılan sertlik cihazı arasındaki korelasyon katsayıları Pink Lady için 0.75 ve Pacific Rose için 0.83 bulunmuştur. Penetrasyon ile elde edilen sertlik değerinin akustik sertlik değerine kıyasla örnekteki su kaybına daha az duyarlı olduğu belirlenmiştir.

Guava meyvesinin raf ömrünü arttırmak amaciyla metil jasmonat $(\mathrm{MJ})$ ve kalsiyum klorür $\left(\mathrm{CaCl}_{2}\right)$ uygulamalarının sertlik üzerine etkisi sıkıştırma kuvveti ve akustik tepki yöntemi ile araştırılmıştır [38]. Depolama sırasında hasar veren sıkıştırma testi ve akustik tepki yöntemiyle ölçülen Young modülü değerlerinin benzer şekilde tüm örnekler için zamanla azaldığı gözlenmiştir. Yedi farklı çeşit üzümün farklı hasat dönemlerinde dokusundaki değişikliklerin incelendiği bir çalışmada, akustik tepki kuvveti yüzey yer değiştirmesinin bir fonksiyonu olarak belirlenmiş̧tir [39]. Genliğin frekansa bağlı değişimi incelendiğinde meyvenin olgunlaşması ile frekansın önemli düzeyde azaldığı bulunmuştur.

Mao vd. [40] tarafından yapılan çalışmada, karpuzun sertliğini incelemek amacıyla paslanmaz çelik, cam ve kauçuk gibi farklı malzemelerden üretilmiş toplar ile örneklere darbe uygulanmış ve örneğin yerleştirildiği polipropilen plastik ve doğal kauçuktan yapılan farklı tepsilerin spektrum üzerindeki etkisi araştırılmıştır. Frekanstan elde edilen sonuçlara göre paslanmaz çelik topun ve plastik tepsinin akustik yöntemle sertlik belirlemede en uygun malzemeler olduğu görülmüştür. Ayrıca sertlik katsayısı $f^{2} m\left(\mathrm{R}^{2}=\right.$ $0.72)$, birinci dereceden moment indeksi $\left(R^{2}=0.73\right)$ ve ikinci dereceden moment indeksi $\left(R^{2}=0.73\right)$ olmak üzere üç sertlik indeksinin karpuzun sertliği ile ilişkili olduğu belirlenmiştir. Karpuzun olgunluk sürecinde sertlik ile f değerinin azalıp, kütlenin arttığı ve birinci dereceden moment indeksinin sertlik değerlendirmesinde kullanım potansiyelinin yüksek olduğu belirlenmiştir. Akustik tepki yanıt sinyallerinin dalgacık çoklu çözünürlük ayrışması (WMRD) tekniği ile karpuz olgunluğunun incelediği bir çalışmada, WMRD analizini istatistiksel bir hipotez testi ile birleştirerek olgun karpuzları olgunlaşmamış 
olanlardan ayırt etmek için yeni bir istatistiksel prosedür önerilmiştir [41]. Kaydedilen akustik sinyallerin Fourier dönüşümleri işlenerek örneklerin doğru sınıflandırılması amacıyla ortaya koyulan prosedürün olgun karpuzları \%93, olgun olmayan örnekleri \%90 oranında doğru sınıflandırdığı belirlenmiştir. Karpuzların iç kusurlarını belirlemek amacıyla yapılan bir başka çalışmada, akustik spektrumun farklı frekans aralıklarında akustik parametreleri değerlendirilmiş ve $85-160 \mathrm{~Hz}$ frekans aralığındaki ölçümlerin daha doğru sonuçlar verdiği saptanmıştır. Bunun yanında akustik yöntemle değerlendirilen karpuz sağlamlığının (\%89.2), konuda eğitimli uzmanlardan tarafından yapılan sınıflandırmadan daha yüksek doğruluğa (\%82.5) sahip olduğu bulunmuştur [42].

Bu yöntem meyve ve sebzeler dışında peynir çeşitlerinde olgunlaşmaya bağlı oyuk oluşumunu belirlemek amacıyla kullanılmıştır [43]. Emmental tipi peynirde akustik ölçümler olgunlaşma sürecindeki değişmeler incelenmiş olup, akustik ölçümlerde frekans band1; düşük $(0-50 \mathrm{~Hz})$, orta $(50-500 \mathrm{~Hz})$ ve yüksek $(500-1200$ $\mathrm{Hz}$ ) frekans aralıklarına bölünmüştür. Düşük bant frekanslarında olgunlaşmaya bağlı olarak bant frekansı $\% 20$ azalmış, ancak orta frekans bandında bu azalma daha düşük düzeyde gerçekleşmiştir. Buna karşın enstrümantal doku analizi ve nem tayiniyle yapılan değerlendirmelerde ise oyuk oluşumunun tespit edilemediği belirlenmiştir.

Bu yöntemle elde edilen tahmini değerlerin hassasiyeti sadece akustik parametrenin seçimine değil, aynı zamanda istatistiksel modelleme yönteminin seçimine de bağlıdır. Doğrusal modelleme teknikleri incelendiğinde, özellikle tekli doğrusal regresyon, kısmi en küçük kareler regresyon, kademeli çoklu doğrusal regresyon yöntemlerinin birçok meyvenin kalite değerlendirmesinde yaygın olarak kullanıldı̆̆ görülmektedir [44, 45].

\subsection{Lazer Doppler Titreşim (LDV) Yöntemi (Laser Doppler Vibration Method)}

Bu yöntemde yansıtıcı bir filmle kaplanmış gıda örneği, titreşim üreteci üzerindeki zemine yerleştirilerek (Şekil 2), 0-3.2 kHz aralığındaki frekanslarda sinüs dalgası sinyalleri ile uyarılmaktadır [46-47]. Numunenin yüzeyinde oluşan titreşim tepkisi, lazer titreşim ölçer (LDV) kullanılarak temassız olarak ölçülebilmektedir. LDV'den gelen lazer ışını örneğin yüzeyine temas ederken, örnekten yansıyan ışınlar LDV üreteci tarafından algılanıp FFT analizörüne iletilmektedir [47]. Ürün yüzeyine gönderilen ve ürün yüzeyinden yansıyan titreşim spektrumları arasındaki faz kayması ise FFT işlemcisi tarafindan analiz edilmektedir [46-47].

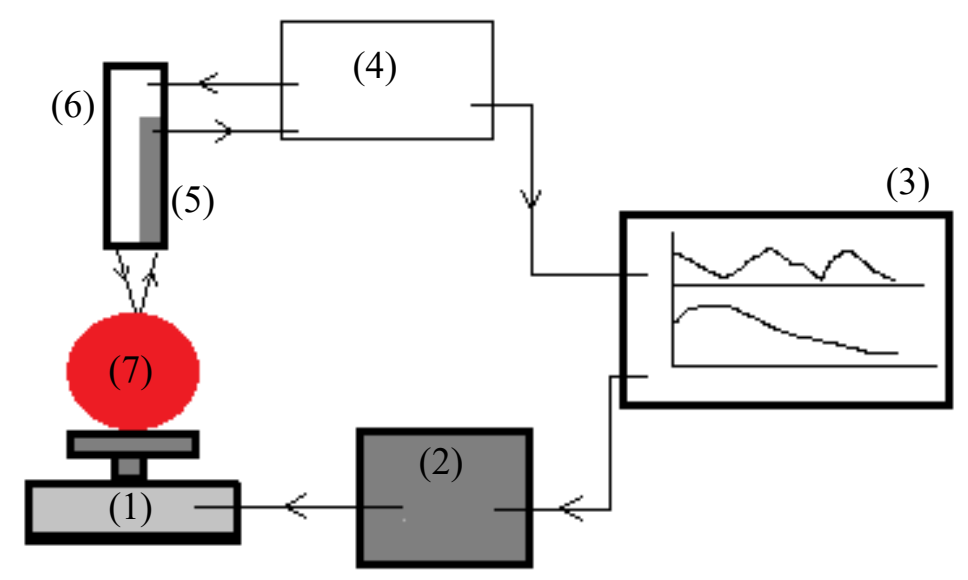

Şekil 2. Lazer Doppler titreşim sistemi; (1): titreşim üreteci, (2): amplifikatör, (3): FFT işlemcisi, (4): LDV lazer üreteci, (5): sensör başlığı, (6): lazer tüpü, (7): örnek (Kaynak: Muramatsu vd., 1999).

Muramatsu vd. [46] tarafından yapılan çalışmada, kivi, şeftali ve armut sertliğini ölçmek ve olgunluğunu değerlendirmek için 5-2000 Hz frekans aralığında sinüs dalgası kullanılmış ve olgunluğa bağlı olarak meyvelerin farklı tepkiler gösterdiği saptanmıştır. 1200-1600 Hz aralığında yer değiştirme kuvveti ile faz kayması arasında korelasyon katsayıs1 0.80-0.92 arasında bulunmuştur ( $\mathrm{p}<0.01) .1200-1600 \mathrm{~Hz}$ aralığında, olgunluğun bir fonksiyonu olarak faz kayması değerinin önemli ölçüde değiştiği gözlemlenmiştir. Ayrıca 
lazer Doppler titreşim ölçerin faz kayması değerleri kullanılarak Hyuganatsu narenciyesinin sağlıklı ve içi hasarlı olanlarının rahatlıkla ayırt edilebileceği belirlenmiştir [46].

Hung vd. [48] tarafından yapılan çalışmada, geliştirilen bir lazer hava üfleme detektörü meyve sertliğinin hasarsız ölçümü için kullanılmıştır. Lazer hava üfleme detektörü bir meyve tutucusu, lazer yer değiştirme sensörü ve havayı solenoid valfe besleyen hava akümülatör tankından oluşmaktadır. Geliştirilen bu detektörle ve hasarlı penetrasyon ölçüm yöntemiyle Dixie Red, Harvester ve Sun Prince çeşidi şeftalilerinin sertlik ölçümleri gerçekleştirilmiştir. Dixie Red için 1994 ve 1995 yıllarında hasat edilen şeftalilerden elde edilen verilere göre, lazer hava üfleme detektörünün penetrometre sertliği ile yüksek ölçüde korelasyon gösterdiği belirlenmiştir $\left(\mathrm{R}^{2}=0.75\right)$. Geliştirilen aynı cihaz elma, kivi ve sentetik topların sertliğini ölçmek için kullanılmış ve cihazın 0.5-8 $\mathrm{MPa}$ arasında sertlik değeri ve $11-30 \mathrm{~mm}$ arasında eğrilik yarıçapında doğru ölçüm yaptığı belirlenmiştir $\left(\mathrm{R}^{2} \sim 0.97\right)$ [49]. Lazer hava üfleme yönteminden elde edilen sertlik değeri ile penetrometre sertlik ölçümleri arasında yüksek bir korelasyon olduğu belirlenmiş $\left(\mathrm{R}^{2} \sim 0.88\right)$ ve lazer hava üfleme yönteminin, sadece kivi ve şeftali gibi sertliği $5 \mathrm{~N}$ 'den düşük olan yumuşak meyvelerin tanımlanması için uygun olduğu belirlenmiştir.

Literatürde armutların titreşim tepkisiyle hasarsız olarak incelendiği birçok çalışma bulunmaktadır. Terasaki vd. [47] tarafından yapılan çalışmada, 1998, 2000 ve 2002 yıllarında hasat edilen armutların olgunluğa bağlı elastik özelliklerindeki değişimi belirlemek için sinüs sinyal genliğini ölçmüşlerdir. Armudun elastikiyet indeksini (EI) hesaplamak için aşağıda verilen denklik kullanılmıştır;

$$
E I=f_{2}^{2} \times m^{2 / 3}
$$

burada $f_{2}$ ikinci rezonans frekans değerini, $m$ ise meyvenin kütlesini (g) göstermektedir. $1500 \mathrm{~Hz}$ 'nin altındaki frekanslarda titreşim tepkilerinin tutarlılı̆̆ 1 ikinci rezonans pikinin tanımlanmasındaki hassasiyeti arttırmaktadır. LDV ile izlenen meyve etinin ortalama EI değeri $6.8 \times 10^{6} \mathrm{~Hz}^{2} \mathrm{~g}^{2 / 3}$ bulunmuştur. 2 hafta-2 ay arasında depolanan armutlarda tüketici beğenisine uygun tekstürel niteliklerin geliştiği ve armut olgunlaştıkça EI değerinde bir düşüş olduğu belirlenmiştir. Yapılan başka bir çalışmada, armutlar LDV ve duyusal testlerle değerlendirilmiş ve optimum yeme olgunluğu süresi için EI değerinin $8.1 \times 10^{4}-1.5 \times 10^{5} \mathrm{~kg}^{2 / 3} \mathrm{~Hz}^{2}$ arasında olması gerektiği bulunmuştur [50]. Ayrıca duyusal test indeksi ile esneklik indeksi arasında yüksek korelasyon olduğu belirtilmiştir $(p<0.01)$.

Zhang vd. [51] armutlar için yaptıkları çalışmada, $f_{2}, f_{2}$ 'deki genlik $\left(\mathrm{A}_{2}\right)$ ve 400, 800, 1200 ve $1600 \mathrm{~Hz}$ 'de faz kaymaları $\left(\mathrm{P}_{400}, \mathrm{P}_{800}, \mathrm{P}_{1200}\right.$ ve $\left.\mathrm{P}_{1600}\right)$ elde edilip, EI değerleri hesaplanmıştır. Maksimum kuvvet, meyve eti sertliği (FF) ve titreşim parametreleri arasında korelasyon çok düşük bulunmuş ve en yüksek korelasyon meyve eti sertliği ve EI değeri arasında gözlenmiştir $\left(R^{2}=0.76\right)$. Sertlik değeri, tüm titreşim parametreleri ile yüksek korelasyon göstermiştir ( $p<0.01)$, ancak en önemli parametrelerin EI, $f_{2}$ ve $\mathrm{P}_{400}$ değerleri olduğu aktarılmıştır. Zhang vd. [52] tarafından yapılan diğer bir çalışmada, armutların sertliklerini belirlemek için iki nokta algılamalı bir piezoelektrik dönüştürücü düzeneği geliştirilerek, farklı şekle sahip armutların frekansa dayalı sertlik indeksleri ile penetrasyon sertliği arasındaki korelasyon incelenmiştir. Farklı şekilli armutların modal analizi ile belirlenen meyve şekli ile $f_{l}$ ve $f_{2}$ frekanslarının doğrusal ilişkilerine göre, yeni çift frekanslı bir sertlik indeksi formülü geliştirilmiştir;

$$
S_{f 1, f 2}=\left(0.6 f_{1}+0.4 f_{2}\right) \times 2 m^{2 / 3}
$$

burada $f_{l}$ meyvenin ekvator kısmındaki rezonans frekansını, $f_{2}$ meyvenin sapa yakın üst kısmından elde edilen rezonans frekansını ve $m$ örneğin kütlesini (g) göstermektedir.

Farklı şekle sahip armut sertliğini ölçmek için Jancsók vd. [53] tarafindan ise iki farklı indeks önerilmiştir. Bunlar;

$$
S_{E_{1}}=\frac{f_{1}^{2}\left(m / m_{0}\right)^{2 / 3} E_{0}}{\left(\alpha_{1} q+b_{1}\right)^{2}}
$$




$$
S_{E_{2}}=\frac{f_{2}^{2}\left(m / m_{0}\right)^{2 / 3} E_{0}}{\left(\alpha_{2} q+b_{2}\right)^{2}}
$$

Bu denklemlerde, $m_{0}$ ve $E_{0}$, sabit olup sırasıyla $100 \mathrm{~g}$ ve $5.84 \mathrm{MPa}$ olarak belirtilmiştir. $\alpha$ ise şekil faktörü olup; $\alpha_{1}$ ve $b_{1}$ küresel şekle, $\alpha_{2}$ ve $b_{2}$ yassı-oval şekle bağlı olan sabitlerdir. Çalışmada Magness-Taylor penetrasyon sertliği ile önerilen çift frekans indeksi $\left(S_{f l, f 2}\right)$ arasında yüksek korelasyon bulunmuştur $\left(\mathrm{R}^{2}=0.95\right)$. Jancsók vd. [53], tarafından üretilen indeks ile çift frekans indeksi karşılaştırıldığında, çift frekans indeksinin doğruluk sınıflandırılmasının daha yüksek olduğu belirlenmiştir. Cuiguan çeşidi armutların sertliğini incelemek için LDV ile çevrimiçi analiz yöntemi kullanılan bir çalışmada, titreşim parametresi olarak tepe değeri (A), $f_{2}$, yarım yükseklikte tepe genişliği (w), tepe alanı (S), EI değeri ve sertlik katsayısı (SC) seçilmiş ve armut sertliği için duyusal değerlendirme sonuçlarına göre farklı sinıflandırma modelleri oluşturulmuştur [54]. Rezonans pikinin, $f_{2}\left(\mathrm{R}^{2}=0.53\right)$, EI $\left(\mathrm{R}^{2}=0.55\right)$ ve $\mathrm{SC}\left(\mathrm{R}^{2}=0.48\right)$ ile orta derecede korelasyon olduğu belirlenmiştir.

Taniwaki vd. [55] yaptıkları çalışmada, Andes ve Quincy çeşidi kavunların esneklik indeksinin zamana göre değişimini incelemişler ve kavun örneklerinin $f_{2}$ değerini LDV kullanarak belirlemiş̧lerdir. Her iki kavun çeşidinin EI değerindeki değişiklikler, yarı üstel ve iki fazlı bozulmalar göstermiş ve kavunların EI açısından optimum tüketim olgunluğunun Andes çeşidi için $4.2-6.3 \times 10^{4} \mathrm{~kg}^{2 / 3} \mathrm{~Hz}^{2}$ ve Quincy çeşidi için $4.5-5.6 \times 10^{4} \mathrm{~kg}^{2 / 3} \mathrm{~Hz}^{2}$ aralığında olduğu belirlenmiştir. Taniwaki vd. [56] tarafından yapılan diğer bir çalışmada, hasat sonrası dönemde Fuyu ve Taishuu çeşidi cennet hurmalarının esneklik ve doku indeksinin zamana göre değişimi LDV kullanılarak araştırılmıştır. Cennet hurmalarının optimum tüketim olgunluğunu (EI) Taishuu çeşidi için; 2.9-6.0×104 $\mathrm{kg}^{2 / 3} \mathrm{~Hz}^{2}$ aralığında iken, Fuyu çeşidi için; $4.8-6.4 \times 10^{4} \mathrm{~kg}^{2 / 3} \mathrm{~Hz}^{2}$ aralığında olduğu belirlenmiştir. Fuyu çeşidinin EI değerinin Taishuu çeşidinden daha yüksek olduğu ve her iki çeşit için EI değerinin 10 günlük depolama sırasında yarı-üstel bir şekilde azaldığı belirlenmiştir (Taishuu; $R^{2}=0.97$ ve Fuyu; $R^{2}=0.99$ ). Ayrıca duyusal test sonuçları ile EI arasında iyi bir korelasyon gözlenmiştir $\left(\mathrm{R}^{2}=0.75\right)$.

Abbaszadeh vd. [57] yaptıkları çalışmada, karpuzların olgunluk sınıflandırılması amacıyla titreşim spektrumlarında gerçekleşen faz kaymasını kısmi en küçük kareler ve çoklu doğrusal regresyon modelleri kullanarak incelemişlerdir. Çoklu doğrusal regresyon modelinin karpuzun olgunluğu belirlemede kullanılan toplam suda çözünür kuru madde (SÇKM), toplam asitlik (TA) ve SÇKM/TA değerini tahminleme gücünün yüksek olduğu bulunmuştur $\left(\mathrm{R}^{2}=0.95-0.99\right)$. Abbaszadeh vd. [58] tarafindan yapılan diğer bir çalışmada ise, sonlu elemanlar modeli ile karpuzun sertlik değerini; karpuzu yeşil (kabuk), beyaz (kabuk içi) ve kırmızı (meyve eti) olarak 3 bölgeye ayırarak incelenmiştir. Deneysel olarak ölçülen rezonans frekansları ile sonlu elemanlar modelinden elde edilen sonuçlar arasındaki fark \%8 olarak bulunmuş ve elde edilen çoklu doğrusal regresyon modelinin $\mathrm{R}^{2}$ değeri 0.99 'dan büyük çıkmıştır. Abbaszadeh vd. [59] sonraki yılda yaptıkları çalışmada, karpuzun meyve eti sertliğini lazer Doppler yöntemiyle incelerken, genlik spektrumu ve faz spektrumunu kısmi en küçük kareler ve aşamalı çoklu doğrusal regresyon analizleriyle değerlendirmişlerdir. Her iki istatistiksel analiz için faz spektrumunun değerlendirilmesiyle yüksek uyumluluk gözlenirken, aşamalı çoklu doğrusal regresyon analizinden elde edilen sonuçlarla, penetrometreyle ölçülen sertlik değeri arasında çok iyi bir korelasyon $\left(\mathrm{R}^{2}=0.99\right)$ olduğu görülmüştür.

Landahl ve Terry [60], avokadoların süpermarketlere gönderilmeden önce depodaki sağlamlığını test etmek için meyvenin kök ve sap kısmına yakın olmak üzere iki farklı noktada LDV ile ölçüm yapmışlardır. RF'leri belirlenen avokadoların Cooke [30] yöntemiyle sertlik değerleri hesaplanmış olup, LDV'nin farklı sertlik değerlerine sahip meyveler arasında ayrım yapabileceği gözlemlenmiştir. Her avokadonun zıt uçlarından eş zamanlı RF değerleri ölçülmüş, ancak çift LDV okumasının önemli bir iyileştirmeye neden olmadığı saptanmıştır.

LDV yönteminin meyve ve sebzelerde kullanımından farklı olarak, bayatlamış ekmeklerin ve yumurta kabuk çatlaklarının belirlenmesi için kullanıldığı görülmektedir. Nouri vd. [61], somun ve baget ekmeklerin serbest titreşim tepkilerini 4 günlük depolama sırasında incelemişlerdir. Ekmeklerde oluşan titreşim ivme sürelerinden sönüm oranını belirlemek için logaritmik azalma analizi kullanılmıştır. Ekmek numunesinin ilk doğal frekansı, titreşim frekansı spektrumundaki ilk tepe değerinin bulunmasıyla belirlenmiştir. $\mathrm{x}$ yönündeki doğal frekans $\left(W_{n x}\right)$ ve z yönündeki doğal frekans $\left(W_{n z}\right)$ değerleri, depolamanın ilk iki günü boyunca istatistiksel olarak değişmezken, depolamanın ilerleyen günlerinde bu değerler azalmıştır. $\mathrm{x}$ 
yönündeki sönümleme oranı $\left(\xi_{x}\right)$ ve z yönündeki sönümleme oranı $\left(\xi_{z}\right)$, depolama süresi boyunca azalma eğilimi göstermiştir. Taze ekmekte titreşimin daha hızlı azaldığı ve depolanan ekmeklere göre daha yüksek sönümleme kapasitesinin olduğu gözlemlenmiştir. Daha sert olan bayat ekmeklerin daha düşük titreşim sönümleme kabiliyetine sahip olduğu, dolayısıyla titreşim sırasında daha az enerji harcadığı bulunmuştur. Titreşim yanıtlarındaki değiş̧iklikler ile enstrümantal doku parametreleri arasında önemli düzeyde ilişki olduğu görülmüştür $(p<0.001)$. Strnková vd. [62] çalışmasında ise, yumurta kabuğunun tepki yanıtına dayalı olarak kabuğu sağlam veya çatlak olan yumurtalar incelenmiştir. Kabuğunda çatlak bulunan yumurtaların frekans tepki sinyallerinin homojen olmadığı ve pik frekanslarının dağılmış olduğu belirlenmiş̧ir. Ayrıca yumurtaya uygulanan tepki ile çatlak bölge arasındaki mesafenin yanıt sinyalleri üzerinde önemli bir etkisi bulunduğu saptanmıştır.

Akustik titreşime dayalı tarımsal ürünlerin kalite kontrolü ile ilgili mevcut çalışmaların çoğunluğu doku ölçümüne odaklanmaktadır. Akustik titreşim yöntemleriyle ölçülen titreşim parametreleri ile geleneksel hasar veren yöntemlerle ölçülen doku indeksleri arasındaki korelasyonun yüksek olduğu birçok çalışmada gösterilmiştir [63].

Tarımsal ürünlerde mikro düzeyde olan değişimler hücre turgor basıncı ile ilgili olup, bu değişimler akustik titreşim karakteristikleri ile belirlenebilmektedir [64, 65]. Hücre turgor basınc1, hücrenin su kaybiyla birlikte azalmaktadır. Bu nedenle tarımsal ürünlerin akustik titreşim özellikleri depolama sırasında sürekli olarak değişmektedir. Örneğin, meyvelerin RF'leri depolama süresince nem kaybına bağlı olarak azalmaktadır [50]. MT sertliği, hasar veren şekilde elde edildiği için, hücre duvarı yapısının bozulması sonuçlarda değişime yol açmaktadır [64, 66]. Yapılan çalışmalar incelendiğinde MT sertliği ile akustik sertlik arasındaki korelasyonların bazı meyve çeşitlerinde yüksek olmadığı görülmektedir [51, 67-69]. Bunun nedeninin her iki yöntemle ölçülen doku sonuçlarının, tarımsal ürünlerin dokusunun farklı yönlerini yansıtmasından kaynaklandığı düşünülmektedir.

Akustik ölçüm yöntemleri değerlendirilirken korelasyonun yanı sıra tekrarlanabilirlik ve ölçüm hassasiyetinin dikkate alınması gerekmektedir. Titreşim parametrelerinden rezonans frekanslarının, birçok çalışmada oldukça iyi tekrarlanabilirlik gösterdiği belirlenmiştir [27,70-72]. LDV ile akustik titreşim yönteminin, penetrometre testinden daha iyi tekrarlanabilirliğe sahip olduğu görülmektedir. Genel olarak, akustik titreşim yöntemleri sadece tarımsal ürünlerin dokusunu değerlendirmekle kalmamakta, aynı zamanda tekrarlanabilirlik ve hassasiyet açısından geleneksel penetrometre yöntemlerinden daha üstün özellikler gösterdiği görülmektedir [61].

Tablo 2. Karpuz kalite özelliklerinin akustik yöntemlerle incelenmesi

\begin{tabular}{|c|c|c|c|c|}
\hline Hasarsız yöntem & Amaç & $\begin{array}{c}\text { İstatistiksel } \\
\text { parametreler* }\end{array}$ & Doğruluk & Kaynak \\
\hline \multirow{5}{*}{ Akustik ölçüm } & \multirow{3}{*}{ Olgunluğun belirlenmesi } & \multirow{3}{*}{ Hatasiz oran } & $\% 77.0$ & {$[73]$} \\
\hline & & & $\% 89.0$ & {$[74]$} \\
\hline & & & $\% 91.8$ & [41] \\
\hline & Sertlik belirlenmesi & $\mathrm{R}^{2}$ & $\begin{array}{c}\% 73.9 \\
\text { (kalibrasyon) } \\
\% 68.4 \\
\text { (validasyon) }\end{array}$ & {$[40]$} \\
\hline & İç kusurların belirlenmesi & Hatasız oran & $\% 82.0$ & [17] \\
\hline \multirow{2}{*}{ LDV } & \multirow{2}{*}{ Sertlik belirlenmesi } & $\mathrm{R}^{2}$ & $\% 41.0$ & [75] \\
\hline & & $\mathrm{R}^{2}$ & $\% 99.0$ & [59] \\
\hline
\end{tabular}

$* \mathrm{R}^{2}$ : korelasyon katsayıs1

\subsection{Ultrason Yöntemi (Ultrasound Method)}

Ultrason, insan kulağının işitme sınırı olan $20 \mathrm{kHz}$ 'i aşan frekansa sahip ses dalgaları olarak tanımlanmaktadır. Ultrasonik bir dalganın bir malzemeden iletilmesi, malzemedeki kimyasal bağların 
sıkışmasına ve uzamasına bağlıdır. Ultrasonik özelliklerin, incelenen örneğin yapısındaki bağların sayısı ve kuvvetine dolayısıyla yığın yapısı ve bileşimine bağlı olduğu belirlenmiştir [76]. Düşük güçlü ultrason, $1 \mathrm{~W} / \mathrm{cm}^{2}$ nin altındaki yoğunluk ve $100 \mathrm{kHz}$ 'den yüksek frekanslara sahip olup, depolama sırasında çeşitli gıda maddelerinin hasarsız analizi ve kalitesinin izlenmesi amacıyla kullanılabilmektedir [77].

Ultrasonik ölçümler genel olarak sertlik ölçümünde veya yaralanma gibi doku hasarları ile iç kusurları belirlemekte kullanılmaktadır [78-81]. Meyve ve sebzelerde en başarılı ultrasonik ölçümler, yüzey dalgası iletim teknikleri kullanılarak elde edilmektedir. Ultrasonik sistem, bir ultrasonik titreşim alıcı, bir çift ultrasonik dönüştürücü ve veri toplama analizi için bir mikro bilgisayar sisteminden oluşmaktadır [77, 82]. Dönüştürücüler, eksenleri arasında yaklaşık $120^{\circ}$ 'lik bir açı olacak şekilde monte edilmiş ve ultrasonik sinyalin, meyvelerin kabuğu boyunca, uçları arasında birkaç kısa mesafeden iletilmesini ve alınmasını sağlamaktadır. Bir dönüştürücünün bir verici ve bir alıcı olarak hareket ettiği geçişli iletim yönteminde ise, meyve etine ultrasonik bir sinyal verilmekte ve bu sinyalin meyve dokusundan yayılımı ölçülmektedir.

Mango ve avokado meyvesinde FFT spektrumlarının depolama süresi, sertlik, şeker içeriği, asitlik ile olgunluğun değerlendirildiği çalışmada, istatistiksel inceleme amacıyla kısmi en küçük kareler regresyon modeli kullanılmıştır [83]. Ultrasonik spektral modeller tarafından öngörülen parametreler ile ölçülen penetrasyon ve fizyolojik testler arasındaki uyum $\mathrm{R}^{2}=0.64-0.87$ değerleri arasında bulunmuş olup, bu değerlerin sertlik değerinin model uyumu için düşük olduğu gözlenmiştir. Mango ve avokado meyveleri için yapılan başka bir çalışmada ise, avokado ve mango meyvesinin sertliğinin oda sıcaklı̆̆ında depolama sırasında aynı düzeyde azalmış olduğu belirlenmiştir. Hasattan sonraki ilk gün meyveler yaklaşık 90$120 \mathrm{~N}$ arasında sertlik değerine sahipken, 15 günlük depolama sonrası sertliğin $12 \mathrm{~N}$ 'a kadar düşerek meyvelerin çok yumuşak hale geldiği belirlenmiştir [84]. Avokado meyvesinin olgunlaşması sırasında kuru madde içeriğindeki değişikliklerin ultrasonik atenüasyon ölçümleri ile iyi bir korelasyon gösterdiği belirlenmiş ve penetrasyon yöntemi yerine ultrasonik ölçümlerin hasarsız olarak avokado kalitesinin belirlenmesinde kullanılabileceği aktarılmıştır.

Erik ve sera domatesin depolanma sırasında olgunluk ve şeker içeriklerini belirlemek için ultrasonik yöntemin kullanıldığg bir çalışmada, eriğin yumuşama sürecinin başlangıcında sertlik ve ultrasonik atenüasyon arasında korelasyon gözlenmezken, yumuşama işleminin sonunda korelasyonun yükseldiği $\left(\mathrm{R}^{2}=0.72\right)$ gözlenmiştir [82]. Sera domateste sertliğin azalmasıyla ultrasonik dalga atenüasyonunun da azaldığını ve aralarında yüksek korelasyon olduğu gözlemlenmiştir $\left(\mathrm{R}^{2}=0.92\right)$ [85].

Morrison ve Abeyratne [80], portakal kalitesini belirlemek için otomatik ve tarlada pratik olarak uygulanabilen yeni bir ultrasonik dönüştürücü sistemi geliştirmişlerdir. Ortamın fiziksel bileşimini tanımlamak için farklı akustik empedans sınırlarında ultrasonik enerjinin yansımaları kullanılmıştır. Ultrasonik enerjiye yansıyan oran aşağıdaki gibi belirlenmiştir;

$$
\Gamma=\frac{\left(Z_{1}-Z_{2}\right)^{2}}{\left(Z_{1}+Z_{2}\right)^{2}}
$$

burada $Z_{1}$ ve $Z_{2}$ sınırın her iki tarafındaki ortamın akustik empedansını göstermektedir. Oluşturulan darbeyankı ultrason tekniğinde, dönüştürücü ve ortam arasında bağlantı jeli kullanılmadığında mikroskobik hava ceplerinin oluştuğu görülmüştür. Bunun da ölçüm sırasında akustik empedans uyumsuzluğuna neden olacağ1 düşünüldüğünden, dönüştürücü ve ortam arasında bir bağlantı jeli kullanımı önerilmiştir. Geliştirilen bu yöntemle, hasat sonrası portakalların kalitesi yüksek bir doğrulukla hasarsız olarak belirlenmiştir.

Saggin vd. [76], peynir, az yağlı peynir, salam, az yağlı salam ve kızılcık sosu gibi çeşitli gıda ürünlerinin ses hızını ve ürün kalınlığını ölçmek için yeni bir hava bağlantılı ultrasonik dönüştürücü ve sinyal üreteci kullanmışlardır. Gıdalar, keskin bir bıçak ile 5-15 mm kalınlığında paralel şeritler halinde kesilmiş ve şeritlerin kalınlığ kumpas ile ölçülmüştür. Ultrasonik yöntemle gerçekleştirilen ölçümle kumpasla ölçülen kalınlık arasında iyi bir korelasyon olduğu belirlenmiştir $\left(\mathrm{R}^{2}=0.99\right)$. Ultrasonik ölçüm ayrıca Çedar, az yağlı Çedar, Asiago, Romano ve Parmesan peynirlerinin sertliğinin incelenmesinde kullanılmış ve sonuçlar Young modülü ile kıyaslanmıştır [86]. Ultrason hızı ile peynirlerin mekanik özellikleri arasında yüksek düzeyde korelasyon $\left(\mathrm{R}^{2}>0.9\right)$ olduğu belirlenmiş, ancak ultrason enerjisinin zayıflama katsayısı ile mekanik 
özellikleri arasında anlamlı bir ilişki bulunamamıştır. Bu tekniğin, gıda ürünlerinin kalınlığını ve mekanik özelliklerini hasarsız ve doğru olarak tespitinde yüksek potansiyele sahip olduğu belirtilmiştir.

Nowak vd. [87], domuz etinin longissimus dorsi kasının lifleri boyunca ses hızının belirlenmesi için beş farklı ultrasonik ölçüm yöntemi denemişler ve ilk iki yöntemde analiz edilen örnekte tek bir ultrason sinyali, sonraki iki yöntemde farklı kalınlıklara sahip örneklerden iki ultrason sinyali, son yöntemde ise analiz edilen örnekte tek bir ultrason sinyali ile ultrasonik dönüştürücüler arasında bulunan mesafedeki damıtılmış suda tek bir ultrason sinyalinin alınması denenmiştir. Sonuç olarak ilk iki yönteminin domuz etinde iletilen ses hızını belirlemek için diğer yöntemlerden daha az etkili olduğu belirlenmiştir. Üçüncü ve dördüncü yöntemin domuz kas dokusunda ses hızının belirlenmesi için uygun yöntemler olduğunun belirlenmesi ile bu yöntemlerin sadece sıvılar için değil, aynı zamanda et gibi katı gıdalar için de uygulanabilir olduğu gösterilmiştir. Yapılan bir başka çalışmada, kuru kürlenmiş et ürünlerinin karakterizasyonu için iki farklı temassız ultrasonik teknik uygulanmıştır [88]. İlk olarak, dilimlenmiş kuru kürlenmiş ve üç farklı paket kalınlığında vakum altında paketlenmiş jambon numunelerinde hava bağlantılı ultrasonik ölçümler gerçekleştirilmiş ve bu ölçümler temaslı ultrasonik ölçümlerle karşılaştırılmıştır. İkinci olarak, kuru kürlenmiş jambon ve İspanyol sucuğu (chorizo) örneklerinde yağlı ve yağsız kısımlar ile bunların dağılımını karakterize etmek amacıyla akustik görüntüleme ve akustik mikroskopi (SAM) yöntemleri kullanılarak ölçümler yapılmıştır. Vakum altında paketli örneklerin tüm ölçüm bölgeleri göz önüne alındığında, hem kalınlık hem de ultrasonik hız için hava bağlantılı ve temaslı ölçümler arasında anlamlı doğrusal bir ilişki elde edilmiş $(\mathrm{p}<0.05)$ ve bunların korelasyon katsayıları kalınlık için; $\mathrm{R}^{2}=0.98$, ultrasonik hız için; $\mathrm{R}^{2}=0.88$ bulunmuştur. Kuru kürlenmiş jambon için yağlı ve yağsız dokuların olduğu bölgeler SAM ile incelendiğinde, görüntülerde aydınlık bölgenin yağ dokusunu, karanlık bölgenin ise yağsız dokuyu temsil ettiği belirlenmiştir. Chorizo örneğinde ise, farkl1 seviyelerde geri saçılma gözlenmiş, bu durumun ise numunenin heterojen yapısından kaynaklandığı belirtilmiştir. Sonuç olarak, SAM, analitik amaçlar için kullanılabilen mikroskobik ölçekte yağ dağılımını tanımlamak için güvenilir bir teknik olabileceği düşünülse de daha fazla çalışma yapılarak elde edilen sonuçların doğruluğunun değerlendirilmesi gerektiği aktarılmıştır.

\section{SONUÇ (CONCLUSION)}

$\mathrm{Bu}$ derlemede, ağırlıklı olarak meyve ve sebzelerin sertliği, iç kusurları ve bileşiminin hasarsız şekilde belirlenmesini sağlayan akustik yöntemler incelenmiştir. Akustik yöntemler, analiz edilecek gıda örneğinde çarpma, titreşim, ses dalgası gibi etkilerden dolayı oluşan titreşim sinyallerinin toplanmasının ve bunların istatistiksel analizini içermektedir. Gıdaya temas eden akustik çarpma ve akustik titreşim gibi yöntemler gıdada herhangi bir hasar oluşturmadığı için bu yöntem örneklerin tekrar kullanılabilme ve aynı örnek üzerinden sayısız ölçüm yapılabilme şansını artırmaktadır. Örneklerin incelenen özellikleri değerlendirildiğinde; hasar veren analiz yöntemlerinden elde edilen sonuçlar ile akustik ölçüm yöntemleri arasında iyi bir korelasyon olduğu görülmektedir. Özellikle kavun veya karpuz gibi büyük hacimli meyvelerde hasarlı analiz yöntemleri büyük miktarlarda örnek kaybına yol açması ve incelenen bir örneğin tüm örnek topluluğunu temsil etme yeteneğinin düşük olması sebebiyle hasarsız analiz yöntemlerinin geliştirilmesinin ekonomik avantajları olacağı açıktır. Gıdalara hasar veren yöntemler yerine taşınabilir, pratik, çevrimiçi, gerçek zamanlı, hassas, doğru ve tekrarlanabilir sonuçlar elde edilen hasarsız yöntemlerin kullanım potansiyelinin yüksek olduğu görülmektedir. Hasarsız yöntemlerin geliştirilerek daha tutarlı sonuçlar elde etmek için elde edilen verilen istatistiksel analizini kolaylaştıran, özellikle yapay zeka gibi yöntemlerin adapte edilmesiyle gıda kalitesinin hızlı ve doğru bir şekilde belirlenmesi sağlanacaktır. Akustik yöntemler gibi diğer hasarsız analiz yöntemlerinde yapılacak iyileştirmeler sayesinde gıda kayıları azaltılabilecektir.

\section{KAYNAKLAR (REFERENCES)}

[1] O. Lamikanra, Eds., Fresh-Cut Fruits and Vegetables: Science, Technology, and Market, CRC Press, (2002).

[2] C. J. Studman, Computers and electronics in postharvest technology: A review, Computers and Electronics in Agriculture, 30 (2001) 109-124. 
[3] B. M. Nicolaï, T. Defraeye, B. De Ketelaere, E. Herremans, M. L. Hertog, W. Saeys, A. Toricelli, T. Vandendriessche and P. Verboven, Nondestructive measurement of fruit and vegetable quality, Annual Review of Food Science and Technology, 5 (2014) 285-312.

[4] M. M. Ali, N. Hashim, S. Bejo and R. Shamsudin, Rapid and nondestructive techniques for internal and external quality evaluation of watermelons: A review, Scientia Horticulturae, 225 (2017) 689-699.

[5] W. H. Su, H. J. He and D. W. Sun, Non-destructive and rapid evaluation of staple foods quality by using spectroscopic techniques: A review, Critical Reviews in Food Science and Nutrition, $57: 5$ (2017) 10391051.

[6] Y. Gao, Q. Li, X. Rao and Y. Ying, Precautionary analysis of sprouting potato eyes using hyperspectral imaging technology, International Journal of Agricultural and Biological Engineering, 11:2 (2018) $153-157$.

[7] B. Li, J. Lecourt and G. Bishop, Advances in non-destructive early assessment of fruit ripeness towards defining optimal time of harvest and yield prediction: A review, Plants, 7:1 (2018) 3.

[8] W. H. Su, D. W. Sun, Multispectral imaging for plant food quality analysis and visualization, Comprehensive Reviews in Food science and Food Safety, 17 (2018) 220-239.

[9] D. W. Sun, Eds., Hyperspectral imaging for food quality analysis and control, Elsevier, (2010).

[10] J. R. Magness and G. F. Taylor, Improved type of pressure tester for the determination of fruit maturity, (1925).

[11] N. N. Mohsenin and H. Gohlich, Techniques for determination of mechanical properties of fruits and vegetables as related to design and development of harvesting and processing machinery, Journal of Agricultural Engineering Research, 7 (1962) 300-315.

[12] K. Kojima, N. Sakurai, S. Kuraishi, R. Yamamoto and D. J. Nevins, Novel technique for measuring tissue firmness within tomato (Lycopersicon esculentum Mill.) fruit, Plant Physiology, 96:2 (1991) 545-550,

[13] J. Irudayaraj, and R. Christoph, Eds., Nondestructive testing of food quality. John Wiley \& Sons, (2008).

[14] D. Kilcast, Eds., Texture in Food: Solid Foods, Elsevier, (2004).

[15] I. E. Elbatawi, An acoustic impact method to detect hollow heart of potato tubers, Biosystems Engineering, 100:2 (2008) 206-213.

[16] C.C. Lien, C. Ay and C. H. Ting, Non-Destructive impact test for assessment of tomato maturity, Journal of Food Engineering, 91:3 (2009) 402-407.

[17] S. A. Mireei, M. Sadeghi, A. Heidari and A. Hemmat, On-line firmness sensing of dates using a nondestructive impact testing device, Biosystems Engineering, 129 (2015) 288-297.

[18] T. C. Pearson, Detection of pistachio nuts with closed shells using impact acoustics, Applied Engineering in Agriculture, 17:2 (2001) 249.

[19] W. Zhang, A. Wang, Z. Lv and Z. Gao, Nondestructive measurement of kiwifruit firmness, soluble solid content (SSC), titratable acidity (TA), and sensory quality by vibration spectrum, Food Science \& Nutrition, 8:2 (2020) 1058-1066.

[20] L. Ragni, A. Berardinelli and A. Guarnieri, Impact device for measuring the flesh firmness of kiwifruits, Journal of Food Engineering, 94:4 (2010) 591-597.

[21] H. L. Clark and M. Walter, U.S. Patent No. 2,277,037. Washington, Dc: U.S. Patent and trademark Office, (1942). 
[22] P. R. Armstrong, M. L. Stone, and G. H. Brusewitz, Peach firmness determination using two different nondestructive vibrational sensing instruments, Transactions of the ASAE, 40:3 (1997) 699-703.

[23] J. De Baerdemaeker, L. Lemaitre and R. Meire, Quality detection by frequency spectrum analysis of the fruit impact force, Transactions of the ASAE, 25:1 (1982) 175-0178.

[24] N. De Belie, S. Schotte, P. Coucke and J. De Baerdemaeker, Development of an automated monitoring device to quantify changes in firmness of apples during storage, Postharvest Biology and Technology, $18: 1(2000) 1-8$.

[25] C. Zhang, N. Wei, E. Gao and Q. Sun, Poisson's ratio of two-dimensional hexagonal crystals: A mechanics model study. Extreme Mechanics Letters, (2020) 100748.

[26] E. E. Finney, Mechanical resonance within red delicious apples and its relation to fruit texture, Transactions of the ASAE, 13:2 (1970) 177-0180.

[27] H. Yamamoto, M. Iwamoto and S. Haginuma, Acoustic impulse response method for measuring natural frequency of intact fruits and preliminary applications to internal quality evaluation of apples and watermelons, Journal of Texture Studies, 11:2 (1980) 117-136.

[28] H. Chen and J. Debaerdemaeker, Effect of apple shape on acoustic measurements of firmness, Journal of Agricultural Engineering Research, 56:3 (1993) 253-266.

[29] J. A. Abbott, Sonic technique for measuring texture of fruits and vegetables, Food Technology, 22 (1968) 635-646.

[30] J. R. Cooke, An interpretation of the resonant behavior of intact fruits and vegetables, Transactions of the ASAE, 15:6, (1972) 1075-1080.

[31] N. Muramatsu, N. Sakurai, R. Yamamoto, D. J. Nevins, T. Takahara, and T. Ogata, Comparison of a non-destructive acoustic method with an intrusive method for firmness measurement of kiwifruit, Postharvest Biology and Technology, 12:3 (1997) 221-228.

[32] H. Li, P. Pidakala, D. Billing and J. Burdon, Kiwifruit firmness: measurement by penetrometer and non-destructive devices, Postharvest Biology and Technology, 120 (2016) 127-137.

[33] J. Sugiyama, T. Katsurai, J. Hong, H. Koyama and K. Mikuriya, Melon ripeness monitoring by a portable firmness tester, Transactions of the ASAE, 41:1 (1998) 121-127.

[34] J. Sugiyama, Application of non-destructive portable firmness tester to pears, Food Science and Technology Research, 7:2 (2001) 161-163.

[35] P. P. Subedi and K. B. Walsh, Non-invasive techniques for measurement of fresh fruit firmness, Postharvest Biology and Technology, 51:3 (2009) 297-304.

[36] S. Schotte, N. De Belie and J. De Baerdemaeker, Acoustic impulse-response technique for evaluation and modelling of firmness of tomato fruit, Postharvest Biology and Technology, 17:2 (1999) 105-115.

[37] F. R. Harker, J. Feng, J. W. Johnston, J. Gamble, M. Alavi, M. Hall and S. L. Chheang, S. L. Influence of postharvest water loss on apple quality: The use of a sensory panel to verify destructive and nondestructive instrumental measurements of texture, Postharvest Biology and Technology, 148 (2019) 32-37.

[38] L. M. Barriga-Téllez, M. G. Garnica-Romo, J. I. Aranda-Sánchez, G. A. Correa, M. C. BartoloméCamacho and H. E. Martínez-Flores, Nondestructive tests for measuring the firmness of guava fruit stored and treated with methyl jasmonate and calcium chloride, International Journal of Food Science \& Technology, 46:6 (2011) 1310-1315.

[39] J. Trnka, P. Pavloušek, Š. Nedomová and J. Buchar, Time and frequency domain response of grape berries to nondestructive impact during the harvesting period, Journal of Texture Studies, 47:1 (2016) 24-33. 
[40] J. Mao, Y. Yu, X. Rao and J. Wang, Firmness prediction and modeling by optimizing acoustic device for watermelons, Journal of Food Engineering, 168 (2016) 1-6.

[41] X. Chen, P. Yuan and X. Deng, Watermelon ripeness detection by wavelet multiresolution decomposition of acoustic impulse response signals, Postharvest Biology and Technology, 142 (2018) 135-141.

[42] B. Diezma-Iglesias, M. Ruiz-Altisent and P. Barreiro, Detection of internal quality in seedless watermelon by acoustic impulse response, Biosystems Engineering, 88:2 (2004) 221-230.

[43] M. González, E. Budelli, N. Pérez and P. Lema, Acoustic techniques to detect eye formation during ripening of Emmental type cheese, Innovative Food Science \& Emerging Technologies, 59 (2020) 102270 .

[44] D. E. Rubio-Diaz, D. M. Francis and L. E. Rodriguez-Saona, External calibration models for the measurement of tomato carotenoids by infrared spectroscopy, Journal of Food Composition and Analysis, 24:1 (2011) 121-126.

[45] C. D. Jones, J. B. Jones and W. S. Lee, Diagnosis of bacterial spot of tomato using spectral signatures, Computers and Electronics in Agriculture, 74:2 (2010) 329-335.

[46] N. Muramatsu, N. Sakurai, N., Wada, R. Yamamoto, T. Takahara, T. Ogata and D. J. Nevins, Evaluation of fruit tissue texture and internal disorders by laser Doppler detection, Postharvest Biology and Technology, 15:1 (1999) 83-88.

[47] S. Terasaki, N. Sakurai, J. Zebrowski, H. Murayama, R. Yamamoto and D. J. Nevins, Laser Doppler vibrometer analysis of changes in elastic properties of ripening 'La France'pears after postharvest storage, Postharvest Biology and Technology, 42:2 (2006) 198-207.

[48] Y. C. Hung, S. E. Prussia and G. O. I. Ezeike, Nondestructive firmness sensing using a laser air-puff detector, Postharvest Biology and Technology, 16:1 (1999) 15-25.

[49] V. A. McGlone, S. M. W. Ko and R. B. Jordan, Non-contact fruit firmness measurement by the laser air-puff method, Transactions of the ASAE, 42:5 (1999) 1391.

[50] M. Taniwaki, T. Hanada, M. Tohro and N. Sakurai, Non-destructive determination of the optimum eating ripeness of pears and their texture measurements using acoustical vibration techniques, Postharvest Biology and Technology, 51:3 (2009) 305-310.

[51] W. Zhang, D. Cui and Y. Ying, Nondestructive measurement of pear texture by acoustic vibration method, Postharvest Biology and Technology, 96 (2014) 99-105.

[52] H. Zhang, J. Wu, Z. Zhao and Z. Wang, Nondestructive firmness measurement of differently shaped pears with a dual-frequency index based on acoustic vibration, Postharvest Biology and Technology, 138 (2018) 11-18.

[53] P. T. Jancsók, L. Clijmans, B. M. Nicolaï and J. De Baerdemaeker, Investigation of the effect of shape on the acoustic response of 'conference'pears by finite element modelling, Postharvest Biology and Technology, 23:1 (2011) 1-12.

[54] C. Ding, H. Wu, Z. Feng, D. Wang, W. Li and D. Cui, Online assessment of pear firmness by acoustic vibration analysis, Postharvest Biology and Technology, 160 (2020) 111042.

[55] M. Taniwaki, M. Takahashi and N. Sakurai, Determination of optimum ripeness for edibility of postharvest melons using nondestructive vibration, Food Research International, 42:1 (2009) 137-141.

[56] M. Taniwaki, T. Hanada and N. Sakurai, Postharvest quality evaluation of Fuyu and Taishuu persimmons using a nondestructive vibrational method and an acoustic vibration technique, Postharvest Biology and Technology, 51:1 (2009) 80-85. 
[57] R. Abbaszadeh, A. Rajabipour, H. Ahmadi, M. J. Mahjoob and M. Delshad, Prediction of watermelon quality based on vibration spectrum, Postharvest Biology and Technology, 86 (2013) 291-293.

[58] R. Abbaszadeh, A. Rajabipour, H. Sadrnia, M. J. Mahjoob, M. Delshad and H. Ahmadi, Application of modal analysis to the watermelon through finite element modeling for use in ripeness assessment, Journal of Food Engineering, 127 (2014) 80-84.

[59] R. Abbaszadeh, A. Rajabipour, Y. Ying, M. Delshad, M. J. Mahjoob and H. Ahmadi, Nondestructive determination of watermelon flesh firmness by frequency response, LWT-Food Science and Technology, 60:1 (2015) 37-640.

[60] S. Landahl and L. A. Terry, Non-destructive discrimination of avocado fruit ripeness using laser S. Doppler vibrometry, Biosystems Engineering, 194 (2020) 251-260.

[61] M. Nouri, B. Nasehi, S. A. Mehdizadeh and M. Goudarzi, M. A novel application of vibration technique for non-destructive evaluation of bread staling, Journal of Food Engineering, 197 (2017) 4447.

[62] J. Strnková, Š. Nedomová, J. Trnka, J. Buchar and J. Simeonovová, Behavior of cracked eggs at nondestructive impact, Journal of Microbiology, Biotechnology and Food Sciences, 9:4 (2020) 43-50.

[63] W. Zhang, Z. Lv and S. Xiong, Nondestructive quality evaluation of agro-products using acoustic vibration methods: A review, Critical Reviews in Food Science and Nutrition, 58:14 (2018) 2386-2397.

[64] M. L. Hertog, R. Ben-Arie, E. Róth and B. M. Nicolaï, Humidity and temperature effects on invasive and non-invasive firmness measures, Postharvest Biology and Technology, 33:1 (2004) 79-91.

[65] R. Lu, A. K. Srivastava and R. M. Beaudry, A new bioyield tester for measuring apple fruit firmness, Applied Engineering in Agriculture, $21: 5$ (2005) 893-900.

[66] P. Sirısomboon, M. Tanaka, S. Fujıta, and T. Kojıma, Relationship between the texture and pectin constituents of Japanese pear, Journal of Texture Studies, 31:6 (2000) 679-690.

[67] I. Shmulevich, R. Ben-Arie, N. Sendler and Y. Carmi, Sensing technology for quality assessment in controlled atmospher, Postharvest Biology and Technology, 29:2 (2003) 145-154.

[68] D. Molina-Delgado, S. Alegre, J. Puy and I. Recasens, Relationship between acoustic firmness and Magness Taylor firmness in Royal Gala and Golden Smoothee apples, Food Science and Technology International, 15:1 (2009) 31-40.

[69] Y. B. Yurtlu, Comparison of nondestructive impact and acoustic techniques for measuring firmness in peaches, Journal of Food, Agriculture \& Environment, 10:2:1 (2012) 180-185.

[70] P. Armstrong, H. R. Zapp and G. K. Brown, Impulsive excitation of acoustic vibrations in apples for firmness determination, Transactions of the ASAE, 33:4 (1990) 1353-1359.

[71] P. Chen, Z. Sun and L. Huarng, Factors affecting acoustic responses of apples, Transactions of the ASAE, 35:6 (1992) 1915-1920.

[72] J. Wang, A. H. Gomez and A. G. Pereira, Acoustic impulse response for measuring the firmness of mandarin during storage, Journal of Food Quality, 29:4 (2006) 392-404.

[73] S. R. M. S. Baki, I. M. Yassin, A. H. Hasliza and A. Zabidi, Non-destructive classification of watermelon ripeness using Mel-frequency cepstrum coefficients and multilayer perceptrons, In The 2010 International Joint Conference on Neural Networks, (2010) 1-6. IEEE.

[74] W. Zeng, X. Huang, S. M. Arisona and I. V. McLoughlin, Classifying watermelon ripeness by analysing acoustic signals using mobile devices, Personal and Ubiquitous Computing, $18: 7$ (2014) 1753-1762. 
[75] D. Cui, Z. Gao, W. Zhang and Y. Ying, The use of a laser Doppler vibrometer to assess watermelon firmness, Computers and Electronics in Agriculture, 112 (2015) 116-120.

[76] R. Saggin and J. N. Coupland, Non-contact ultrasonic measurements in food materials, Food Research International, 34:10 (2001) 865-870.

[77] T. S. Awad, H. A. Moharram, O. E. Shaltout, D. Asker and M. M. Youssef, Applications of ultrasound in analysis, processing and quality control of food: A review, Food Research İnternational, 48:2 (2012) 410-427.

[78] B. E. Verlinden, V. De Smedt and B. M. Nicolaï, Evaluation of ultrasonic wave propagation to measure chilling injury in tomatoes, Postharvest Biology and Technology, 32:1 (2004) 109-113.

[79] I. Aboudaoud, B. Faiz, E. Aassif, A. Moudden, D. Izbaim, D., Abassi and M. Azergui, The maturity characterization of orange fruit by using high frequency ultrasonic echo pulse method, In IOP Conference Series: Materials Science and Engineering, 42:1 (2012) 012038, IOP Publishing.

[80] D. S. Morrison, and U. R. Abeyratne, Ultrasonic technique for non-destructive quality evaluation of oranges, Journal of Food Engineering, 141 (2014) 107-112.

[81] S. Hitchman, K. van Wijk and Z. Davidson, Monitoring attenuation and the elastic properties of an apple with laser ultrasound, Postharvest Biology and Technology, 121 (2016) 71-77.

[82] A. Mizrach, Assessing plum fruit quality attributes with an ultrasonic method, Food Research International, 37:6 (2004) 627-631.

[83] A. Mizrach, U. Flitsanov, Z. E. Schmilovitch and Y. Fuchs, Determination of mango physiological indices by mechanical wave analysis, Postharvest Biology and Technology, 16:2 (1999) 179-186.

[84] A. Mizrach, Determination of avocado and mango fruit properties by ultrasonic technique, Ultrasonics, $38: 1-8(2000) 717-722$.

[85] A. Mizrach, Nondestructive ultrasonic monitoring of tomato quality during shelf-life storage, Postharvest Biology and Technology, 46:3 (2007) 271-274.

[86] B. K. Cho and J. M. K. Irudayaraj, A noncontact ultrasound approach for mechanical property determination of cheeses, Journal of Food Science, 68:7 (2003) 2243-2247.

[87] K. W. Nowak and M. Markowski, A comparison of methods for the determination of sound velocity in biological materials: A case study, Ultrasonics, 53:5 (2013) 923-927.

[88] E. Corona, J. V. Garcia-Perez, T. E. G. Alvarez-Arenas, N. Watson, M. J. Povey and J. Benedito, Advances in the ultrasound characterization of dry-cured meat products, Journal of Food Engineering, 119:3 (2013) 464-470. 